\begin{tabular}{lr|} 
& $\begin{array}{r}\text { Forum Pedagogiczne } \\
11(2021) 1\end{array}$ \\
MARIOLA KOKǪ̧: 24.01.2021 \\
Warszawa, Polska \\
ORCID ID: ooo3-1871-1698
\end{tabular}

\title{
O PRZEDMIOCIE POZNANIA - WYOBRAŹNIA (MUZYCZNA)
}

\begin{abstract}
Streszczenie: Celem artykułu jest przedstawienie refleksji nad wielowymiarowym zagadnieniem wyobraźni. Zaprezentowano definicję i pojęcie wyobraźni oraz wyobrażeń w wybranych kontekstach: wyobraźni twórczej vs odtwórczej, potencjału kreatywności i muzykoterapii. Przybliżono wyobraźnię muzyczną, występującą w modalności słuchowej, sygnalizując terapeutyczny aspekt wyobrażeń muzycznych i wyobraźni.
\end{abstract}

Słowa kluczowe: wyobraźnia (muzyczna), wyobrażenia, kreatywność, muzykoterapia.

\section{Wprowadzenie}

Zagadnienie wyobraźni muzycznej jest przedmiotem zainteresowań dziedziny psychologii muzyki, gdzie dostrzega się złożoność wyobraźni jako procesu - istniejącego w interakcji z właściwościami psychiki ludzkiej. Wyobraźnia określona przez arystotelesowskie pojęcie „fantazja”, czyli zdolność do wytwarzania obrazów mentalnych, przekształcania i udostępniania danych aisthesis w postaci przedstawień (phantasmata), jest przedmiotem filozoficznej refleksji o czynnościach i bytach mentalnych. Metafizyczny, artystyczny i naukowy aspekt funkcji wyobraźni stał się później trójczłonowym wyróżnikiem rozważań szkockiego filozofa D. Hume’a, który jest znany z dążenia do odkrywania naturalistycznego podejścia do nauki o człowieku. Niezależnie od istniejącej różnorodności w opisie filozoficznej myśli o tym zjawisku, wydaje się, że wyobraźnia jest znakiem rozpoznawczym poznania.

* Mariola Kokowska, absolwentka Wydziału Psychologii na Uniwersytecie Społeczno-Humanistycznym w Warszawie oraz Instytutu Wychowania Artystycznego na Uniwersytecie im. Marii Curie-Skłodowskiej w Lublinie, poetka, psycholog i psychoonkolog, muzykoterapeuta, muzyk; e-mail: movischolar@gmail.com. 
Powstaje wszędzie tam, gdzie operacje jednej domeny samorzutnie wchodzą w interakcję z innymi (Barret, 2005). Dyskusja na temat wyobraźni rozpala umysły wielu naukowców, ale jedna $\mathrm{z}$ debat na ten temat odnosi się do wyobraźni rozumianej jako dwojakiego rodzaju zjawisko: a) określające prostą zdolność do tworzenia obrazów odtwarzających rzeczywistość bądź b) określające zdolność tworzenia obrazów, które są nowymi tworami, jako pojawiające się w sposób kreatywny i twórczy reprezentacje świata (wewnętrznego/jednostki i zewnętrznego/otoczenia). Większość teorii wyobraźni dokonuje rozróżnienia między wyobraźnią, rozumianą jako proces, a wyobraźnią, odczytywaną jako myślenie o rzeczywistości, czyli fizycznym otoczeniu dostępnym ludziom dzięki zmysłom. W sensie doświadczenia zmysłowego (wizualnego lub słuchowego), nazywanego niekiedy wyobraźnią „zmysłową”, podkreśla się jej ucieleśniony wymiar - rozważany m.in. przez fenomenologię. Stąd z kolei możliwe jest doświadczanie jej jako aktu (świadomego, dobrowolnego), czegoś możliwego (nie rzeczywistego - stanu rzeczy, obiektu, sytuacji), co jest kluczowe dla ludzkości i jej uczestnictwa w kulturze w pryzmacie twórczości artystycznej. Z fenomenologicznej perspektywy można próbować badać, w jaki sposób nasze mniemania o rzeczywistości/nierzeczywistości, obecności/ nieobecności (rzeczy) są same w sobie umocowane w doświadczeniu - w percepcji lub wyobraźni, a w związku z tym - jakie nam mogą się wydawać. Niezależnie od tego wszystkiego można przyjąć, że wyobraźnia otwiera człowieka na coś innego, na inną przestrzeń, co może być czymś pośrednim między tym, co percepcyjne „tu i teraz”, a tym, co abstrakcyjne - w myśleniu i działaniu. Ponadto wyobraźnia może stanowić model specyficznego, rozszerzonego doświadczenia (patrz: Vygotsky 1971; 2004, s. 9-10) lub model deficytu, który umożliwia lepsze dopasowanie do rzeczywistości przez wypełnienie „luki” (tzw. pętla wyobrażeniowa). Tradycyjne rozumienie wyobraźni jako zdolności podmiotu do swobodnego odtwarzania zmysłowych obrazów rozszerza żywotne ujęcie filozoficzne, w którym nie można mówić o dominującej i jednoznacznie pojmowanej wyobraźni. Jako komponent poznania, wyobraźnia (łac. imaginatio) zawiera w sobie coś nieuchwytnego, pozazmysłowego i magicznego. W fenomenologicznym ujęciu - model wyobraźni jest przejściem od kategorii władzy tworzenia obrazów, do świadomości ich istnienia, doświadczania/ postrzegania w świecie i pojawiania się jako fantazji. Mówiąc o niej, można rozważać ją w kategoriach zdrowia lub psychopatologii, pojawiających się okresowo dysfunkcji (przywidzeń) i diagnozowanych zaburzeń, anomalii. Nie rozwijając dalej tego aspektu, złożony proces poznania związany jest m.in. z symbolicznymi i artystycznymi zdolnościami, niebędącymi rezultatem rozwoju dodatkowych zdolności specyficznych dla danej domeny, ale z częściowym podziałem między domenami (Mithen, 1996). Wyobraźnia - jako proces mentalny akcentujący aspekt zdolności poznawczych - przedstawiana jest $\mathrm{w}$ relacji podmiotu $\mathrm{z}$ otaczającą ją rzeczywistością i ma związek z innymi procesami psychicznymi (Schuman 1956): uwagą, pamięcią, inteligencją i emocjami. Uznawana za zdolność do tworzenia w świadomości tego, co nowe, jest przypominaniem uprzedniego doświadczenia. 
Jest umiejętnością mentalnego wytworzenia bodźców zmysłowych (słuchowych, wzrokowych etc.) w sytuacji ich nie doświadczania, choć podlegały wcześniej spostrzeganiu. W selektywnym wyjaśnianiu zjawiska wyobraźni muzycznej przez psychologię muzyki odwołujemy się do danych neuronaukowych jako podstawy działania zdolności poznawczych (Aganti i in. 2013) bądź do funkcjonalnych analiz danych zjawisk (Cummins 200o). Definicja wyobraźni określa ją jako zdolność do tworzenia wyobrażeń twórczych, aktywujących procesy mentalne (przewidywanie, uzupełnianie i odtwarzanie) oraz umiejętność przedstawiania sobie zgodnie z wolą - sytuacji, osób, przedmiotów, zjawisk dotąd niepostrzeganych wzrokiem (np. fantazja, imaginacja) (Szymczak 1981). Wyobraźnia jest poznawczą podstawą wszelkiej percepcji i twórczości muzycznej, stanowiąc istotę twórczego postrzegania muzyki (Hagreaves i Lamont 2017). Pojęcie wyobraźni występuje w kontekście zdolności estetycznej i reprezentuje sztuki piękne oraz zdolności pozamuzyczne, która określają jakość i poziom osiągnięć muzycznych. Wyobraźnia, jako komponent wnoszenia psychologicznej perspektywy do estetyki sztuki (muzycznej), jest obecna w wielu aktywnościach muzycznych. Do podstawowych czynności muzycznych, identyfikowanych w związku z kontekstem wyobraźni, odnoszą się np. komponowanie, improwizowanie, wykonywanie i/lub słuchanie dzieła muzycznego. Psychologia muzyki sytuuje termin wyobraźnia w kategoriach specyficznych zachowań o charakterze mimowolnym, antycypacyjnym lub dobrowolnym, bądź określa go jako zdolności systemu poznawczego do przetwarzania informacji (np. do tworzenia mentalnych reprezentacji muzyki). W muzykologii kognitywnej wyobraźnia muzyczna jest poznawczą podstawą muzycznej percepcji i produkcji muzycznej (Hargreaves 2012). Współcześnie nadal poszukuje się pełnego i zadowalającego wyjaśnienia tego muzycznego zjawiska, mającego oparcie w równych koncepcjach teoretycznych i empirycznych.

Wyobraźnia - traktowana jako część wewnętrznego życia i inicjator twórczego myślenia - stanowi podbudowę tej zdolności mentalnej. Wspomaga tworzenie nowego i wprowadzanie innowacji, pozwala widzieć sytuacje i problemy z innej perspektywy, ich sposoby rozwiązywania. Swoistą funkcją wyobraźni jest tworzenie nowatorskich rozwiązań, co przekłada się na specyfikę roli wyobrażeń twórczych - przyjmujących dwojakiego rodzaju funkcję: a) uczestniczą w procesie rozwiązywania problemów; b) ujawniają się jako wyobrażenia poprzedzające twórcze rozwiązania, wzbudzając przetwarzanie informacji dającej nowy rezultat (Zdankiewicz-Ścigała, Maruszewski 200o). Myślenie wyobrażeniowe jest zdolnością do obrazowej mentalizacji przyszłego dzieła, zanim zostanie ono wykonane. Kreatywne rozwiązywanie problemów łączy się z procesem uczenia się i nauczaniem (Chang 2012; Hokanson 2006), poszukiwaniem akceptacji (Mrymel 2003), procesami twórczymi, które antycypują przyszłość. Działania twórcze występujące $\mathrm{w}$ procesie rozwiązywania problemów obejmują swym zakresem pojęcie twórczości, występującej w szerokim znaczeniu: a) jako tworzenie czegoś, co jest nowe (np. dzieł sztuki) (Szymaczak 2002); b) jako zdolność do tworzenia wszelkiego 
rodzaju: pomysłów, wytworów, modeli, kompozycji mających status nowatorski (Hurlock 1985), w sytuacji wcześniej nieznanej osobie je wytwarzającej (np. twórczość naukowa, artystyczna, techniczna) (Sokół 2015). Wyobraźnia uczestniczy w procesach decyzyjnych, w rozwiązywaniu problemów, w planowaniu i wszelkiego rodzaju twórczości, a powstające wyobrażenia przywołują pewien stan mózgu, który przypomina percepcję lub fizyczną aktywność ruchową (Buchsbaum i in. 2012).

Z wyobraźnią współwystępuje termin wyobrażenie. Dotyczy aktywności umysłowej podmiotu, w której obraz przedmiotu lub sytuacji w danej chwili nieoddziałujących na narządy zmysłowe opiera się na jej uprzednich spostrzeżeniach i fantazji. Nawiązanie do uprzednich doświadczeń (wspomnienia) decyduje o statusie reprezentacji wyobrażeń odtwórczych - są wiernym i wyrazistym odwzorowaniem obiektów realnych. Wyobrażenia bez aspektu wspomnieniowego, o treści nierzeczywistej, są reprezentacją wyobrażeń twórczych lub fantazyjnych (Szymczak 1981). Wyobrażenia te są nowo powstałym rezultatem intencjonalnych działań w postaci wytworu (np. kompozycja), opartych na poprzednich doświadczeniach podmiotu (spostrzeżenie, wiedza, fantazja). Wyobraźnia jest procesem psychicznym opartym na wyobrażeniach, a wyobrażenie stanowi efekt jej intencjonalnego działania (Zdankiewicz-Ścigała i Maruszewski 200o). Termin fantazja jest rozumiany jako zdolność do wyobrażania sobie czegoś (Szymczak 1981), uczestniczy w procesie wywoływania wyobrażeń lub pojmowana jako osobista skłonność do przywoływania pomysłów i marzeń (Witwicki 1975, s. 342). Myślenie wyobrażeniowe jest zdolnością do zobaczenia lub umieszczenia w swoim umyśle przyszłego dzieła, zanim zostanie ono wykonane. Kreatywne rozwiązywanie problemów jest związane z procesem uczenia się i nauczaniem (Chang 2012; Hokanson 2006), poszukiwaniem akceptacji (Mrymel 2003). Twórczość muzyczna - posługująca się specyficznym wymiarem wyobrażeń i kreacji oraz przekształceń, zawiera spontaniczne tworzenie nowej ścieżki (linku) prowadzącej do rozwiązania problemu muzycznego (np. w kompozycji) (Schubert 2012, s. 124).

Wyobraźnia jest definiowana jako proces psychiczny umożliwiający przetwarzanie wyobrażeń, który jest łączony z dwoma rodzajami przekodowywania informacji w postaci obrazowej: a) izomorficznym (przekształcenia są w obrębie tej samej modalności zmysłowej, np. słuchowej, wzrokowej); b) transmorficznym (przekształcenia są między modalnościami, a transformacje obiektu i relacji pojawiają się jednorazowo lub wielokrotnie). Wyobrażeniom przypisywane są atrybuty, pozwalające na odróżnienie ich od spostrzeżeń lub iluzji (Zdankiewicz-Ścigała, Maruszewski 200o). Do właściwości tych należą: a) podobieństwo między realnym a konstruowanym w wyobraźni obiektem; b) świadomość tego, iż obiekt stanowiący przedmiot wyobrażenia jest niedostępny w danej chwili w sposób zmysłowy; c) ograniczona wyrazistość obrazu; d) zapotrzebowanie na dodatkowe zasoby uwagi; e) wyeksponowanie pierwszoplanowego obiektu wyobrażenia (np. melodii) względem towarzyszącego mu tła. Schemat relacji między pojęciami od najszerszego (wyobraźnia) do najwęższego (fantazja) zakresu przedstawia rysunek 1. 


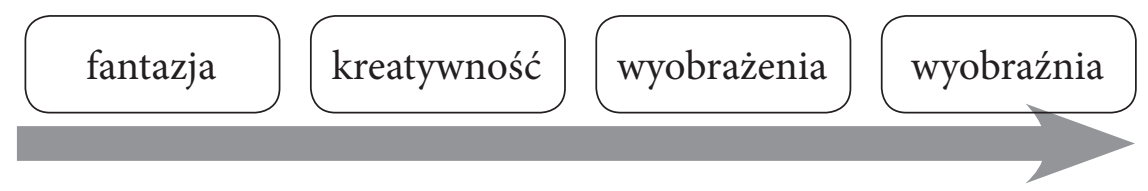

Rysunek 1. Schemat relacji między pojęciami związanymi z wyobraźnią

Źródło: opracowanie własne.

\section{Wyobraźnia twórcza i odtwórcza}

Wyobraźnia, rozumiana jako zdolność człowieka, proces albo stan psychiczny (Limont 1996), czyli dyspozycja do wytwarzania wyobrażeń (tj. obrazów umysłowych) (Maruszewski 2002), podlega wielu klasyfikacjom. Ujmują one zagadnienie wyobraźni w swoiste ramy podziału, przyjmując różnorodne kryteria: a) wyobraźnia słuchowa, wzrokowa, ruchowa (Vernon, za: Hornowski 1987); b) intuicyjna, samorzutna, kombinująca, rozumowa, twórcza (Ribot 1901); c) w. konkretna i oderwana (Witwicki 1962); d) realistyczna i senna (Przetacznikowa 1982). Dowolna modalność zmysłowa wyobraźni i wyobrażeń jest podstawą do ich podziału, spotykanego w literaturze (Lacey, Lawson 2013). Wyobrażenia wzrokowe lub słuchowe (specyficzne: synestezja ${ }^{1}$ ) pojawiają się częściej niż pozostałe, lecz wyobraźnia wizualna uczestniczy w operacjach: tworzenia, interpretacji i transformacji w kodzie ikonicznym (Thompson i in. 2011). Wśród podanych klasyfikacji najbardziej znane jest rozwarstwienie wyobraźni na: 1) twórczą (czynną, wytwórczą) lub 2) odtwórczą (bierną, mimowolną, reproduktywną) (Szmidt 2013), podobnie jak rozdzielenie wyobrażeń na: twórcze lub odtwórcze.

Wyobraźnia twórcza - ma charakter metaforyczny ${ }^{2}$. Generuje nowe i oryginalne jakości, korzystając z zasobów pamięci (Szmidt 2013, s. 199). To proces powstawania nowych wyobrażeń, mających oparcie w spostrzeżeniach, lecz przez ich modyfikację odbiega od właściwości odtwórczych (Pietrasiński 1969, s. 26). Ten rodzaj wyobraźni występuje w sposób świadomie kierowany przez dostosowanie działań do celu, który wyznacza efekt końcowy twórczego myślenia. Właściwości opisujące wyobraźnię twórczą dotyczą: a) klarowności (stopień jasności), pojawiających się obrazów mentalnych (np. wizualnych, słuchowych); b) oryginalności wyobrażeń. Wyobrażenia twórcze powstają wskutek intencjonalnych działań osoby, gdy wyobraźnia odnosi się do części wyobrażenia - tj. powołuje brakujące składniki wyobra-

\footnotetext{
1 Synestezja - polega na łączeniu wrażeń odbieranych różnymi zmysłami. Pobudzenie jednego zmysłu wywołuje wrażenie w innym kanale zmysłowym (Rogowska 2004). Najczęściej spotykana jest syntezja wzrokowo-słuchowa (np. kolorowe słyszenie), rzadziej - wielomodalna.

2 Metafora-tj. przeniesienie, przenośnia. To przeniesienie nazwy jednej rzeczy na inną przy użyciu analogii (Arystoteles). Metafora opiera się na podobieństwie cech wspólnych lub odmiennych.
} 
żenia, tworząc pewien obiekt, bądź odnosi się do całości wyobrażenia - tj. tworzy nowy obiekt, niemający odniesienia do rzeczywistości. W wykonywaniu operacji mentalnych przy tworzeniu wyobrażeń odgrywa pewną rolę transmorficzność, polegająca na przechodzeniu między modalnościami zmysłowymi (ZdankiewiczŚcigała, Maruszewski 200o).

Wyobraźnia odtwórcza polega na wiernym odwzorowywaniu i generowaniu cech realnie istniejących obiektów, w czym pomaga pamięć epizodyczna i schematy pamięciowe. Określana bywa jako pamięć wyobrażeniowa, czyli zdolność do przedstawiania sobie czegoś minionego (nieobecnego) w konkretnej postaci - będącej w analogii do wrażeń. Wyobrażenia odtwórcze występują wskutek samorzutnego pojawiania się i przypisuje się im niższy stopnień świadomości względem wyobraźni twórczej. Ich przejawy można spotkać w postaci marzeń sennych. Przypisuje im się możliwość powołania w każdym momencie, niezależnie od obecności bodźca sensorycznego.

Wyobrażenia, będąc kategorią pojęć poznawczych, uczestniczą w polemice, która dotyczy natury ich istnienia. Istota tego sporu sprowadza się do pytania, czy doświadczenie wyobrażenia ( $w$ sensie fenomenologicznym) odzwierciedla prawdziwą naturę wyobrażeń? Perspektywa obrazowa, czyli analogowa (Kosslyn 1994; Moulton, Kosslyn 2009; Paivio 1986; Paivio, Lambert 1981) ujmuje je w kodzie (wizualnym) w postaci reprezentacji mających własności przestrzenne lub specyficzne dla danych kanałów sensorycznych. Stanowisko propozycjonalne, czyli abstrakcyjne (Anderson 1978; Pylyshyn 2002) wskazuje, że dane zmysłowe są kodowane w postaci abstrakcyjnych zbiorów twierdzeń lub sądów.

Wyobrażenia stanowią umysłowy odpowiednik obiektów (realnie lub możliwie istniejących, będących fikcją), zastępując swe obiekty podczas procesu przetwarzania informacji. Jako dana forma reprezentacji obiektów są raczej nietrwałe, czyli zanikają po doraźnym pojawieniu się w celu stworzenia (np. wyobrażenia, słowa, sądu czy koncepcji). Reprezentacje nietrwałe, czyli obrazy (Kosslyn 2009; Paivio 1986) dotyczą: a) wyobrażeń (poznawcza reprezentacji obiektu w umyśle, podobna do spostrzeżenia, występuje podczas nieobecności obiektu i jest nietrwała, ma odniesienia do systemu niewerbalnego, który działa szybciej względem werbalnego); b) wyobraźni (zdolność do generowania wyobrażeniowych reprezentacji świata: twórcza lub odtwórcza); c) obrazu mentalnego (pozostaje w zależności od reprezentowanego obiektu i występuje jako: konstrukt teoretyczny lub ma analogowy opis) (Johnson-Laird 1980). Możliwy wybór rodzaju reprezentacji, którą kierują się ludzie, prawdopodobnie ma związek $\mathrm{z}$ ich upodobaniami lub zdolnościami (Nęcka 2001, s. 97-98).

\section{Kreatywność - twórczy aspekt wyobraźni}

Fenomenologiczna myśl związana z wyobraźnią i jej rozwojem (Schultz 2009), zwłaszcza filozoficzna, przedstawia wyobraźnię jako zdolność do tworzenia, 
przechowywania i przywoływania obrazów (Arystoteles, za: Asma 2017). Wyobraźnię przeciwstawia się myśleniu dosłownemu, ponieważ zdolna jest ona wyjść poza umysł ograniczony światem empirycznym (Stevens 1951). Twórczy kontekst wyobraźni odnosi się do stanu psychicznego i zdolności natury poznawczej, które mają na celu zmianę pewnego zastanego materiału (muzycznego, obrazu etc.) czy dostępnego już wcześniej pomysłu i przekształcenia go w nowy (Schidt 2008), niepowtarzalny produkt twórczego myślenia (np. artystyczny obiekt estetyczny). Twórcza wyobraźnia - związana z twórczym myśleniem (Nęcka 1995) - jest zdolnością, która wpływa na skuteczne wykorzystanie z twórczego potencjału (Ren $i$ in. 2012). Koncepcje i pomiar kreatywności są przypisywane do psychologii twórczości (np. płynnej) (Nęcka 2001), w której dostrzega się wartość procesów mentalnych i emocjonalno-motywacyjnych w twórczym procesie. Kreacja jest swoistą dyspozycją wyobraźni, łączącą zjawiska w zakresie dziedziny artystycznej (wykonawczej i twórczej) z koncepcjami estetycznymi i funkcjami psychicznymi natury poznawczej. Wyobraźnia pojawia się w aspekcie tworzenia i percepcji odbiorczej obiektów sztuki, doświadczanych wytworów kultury. Jako pewnego rodzaju dyspozycja, kreacja, uczestniczy w kształtowaniu wrażliwości estetycznej podmiotu oraz stanowi źródło twórczości artystycznej.

Kreatywność jest terminem używanym w wielu kontekstach. Wyodrębnia się w nim znaczenie cech osobowości wyróżniających ludzi o wysokim lub niskim nasileniu kreatywności względem mniej twórczych rówieśników (Treffinger i in. 1982). Widziana bywa ona również jako proces, w którym osadzone są etapy twórczej aktywności lub są oceniane zdolności wpływające na kreatywność - podstawę powstałych tworzyw (produktów) lub osiągnięć. W aspekcie kreatywności zwraca się uwagę na rolę wpływu środowiska społeczno-kulturowego w rozwoju i ekspresji twórczości (Treffinger i in. 1982, s. 5), gdzie udział muzyki ma charakter społeczny i może mieć implikacje związane $\mathrm{z}$ odpowiednim wykształceniem (MacDonald, Miell 2000). Kreatywność rozumiana jako zdolność osoby do wytwarzania obiektów mających własną wartość o charakterze twórczym, intelektualnym i pragmatycznym (Zawadzki 2005) wiąże się z interpersonalnością znaczeń, kiedy bada się otwartość na doświadczenie (Batery, Furnham 2006) oraz relację z pozytywnymi afektami (Davis 2009) lub zachowania i potencjał twórczy (Runco 1999, za: Karwowski 2003; Runco 2003, za: Kaufman 20012).

Kreatywność jest zespołem właściwości współzależnych, opartych na bazie konstruktów związanych ze zdolnościami twórczymi oraz myśleniem dywergencyjnym, które dopuszcza wiele rozwiązań. Zasady obowiązujące w myśleniu dywergencyjnym zaproponował J.P. Guillford (1987), wymieniając jego składowe: a) płynność - liczba rozwiązań mówi o zachowaniu twórczym, wskaźnikiem poziomu płynności jest zdolność do wytwarzania w krótkim czasie danej liczby słów, pomysłów (Schmidt 2008); b) giętkość - elastyczność myślenia, otwartość na różne konteksty i patrzenie na problem $\mathrm{z}$ różnych punktów widzenia oraz umiejętność dostosowywania sposobów rozwiązania problemów do zmieniających się 
sytuacji kontekstowych (Schmidt 2009); c) oryginalność myślenia - zdolność do wychodzenia poza stereotypowe rozwiązania, trafność i niezwykłość pomysłu/ rozwiązania (Schmidt 2008); d) elaborację - umiejętność przełamania niechęci umysłowej i starannego dopracowania pomysłu (Torrance 1966). Kreatywność jest traktowana jako odpowiednik potencjału twórczego (Karwowski 2009), którą opisują cechy osobowościowe oraz zdolności twórcze (płynność, giętkość, oryginalność myślenia, zdolność kojarzenia rzeczy pozornie od siebie odległych, sprawność posługiwania się metaforą i analogią (Karwowski 2010, s. 54-55).

\section{Wyobraźnia w modalności słuchowej (muzyczna)}

Właściwością wyodrębniającą wyobraźnię z całego nurtu badawczego jest zainteresowanie występującymi rodzajami modalności zmysłowych, które wyznaczają spektrum uwagi wokół swoistości zjawisk słuchowych. Fizjologiczny słuch muzyczny jest podstawą rozwoju słuchu muzycznego i fonematycznego ( $\mathrm{tj}$. mownego) (Domagała, Mirecka 2012), pozwalającego na percepcję struktur muzycznych i symbolicznej postaci znaków - posiadających swoiste reguły znaczeniowe. Pojęcie wyobraźni i kreatywności w słuchaniu muzyki, wpisane w postrzeganie i percepcję jako twórczą konstrukcję, odwołuje się do sieci skojarzeń poznawczych o aspektach: a) muzycznym - rozumianym jako połączenia między materiałem muzycznym a stylami utworów, tworzących mapy mentalne; b) kulturowym - kulturowe odniesienia w obszarze postrzegania stylu muzycznego przez określone grupy społeczne; c) osobistym - rozumianym jako budowanie osobistych sieci skojarzeń, które są włączane w szersze sieci o charakterze kulturowym, dając namiastkę naszej muzycznej tożsamości. Wyobraźnia (muzyczna) jest traktowana jako ważny składnik uzdolnienia muzycznego i doświadczenie osobiste, wyraża się przez uwewnętrznione wyobrażanie sobie złożonych struktur muzycznych. Jako pojęcie z zakresu psychologii poznawczej wyobraźnia, $w$ aspekcie ogólnym oraz w sensie muzycznym, łączona jest $\mathrm{z}$ takimi zjawiskami, jak: kreatywność, inwencja twórcza, pomysłowość, fantazja, imaginacja, marzenie. Jest ona zaliczana do tzw. muzykalności wyższego rzędu, która bazuje na zjawiskach zdolności pozamuzycznych i cech osobowości oraz doświadczeń życiowych, kształtujących ją w oparciu o muzykalność tzw. podstawową (uwarunkowaną słuchem muzycznym, poczuciem rytmu i zdolnością do wyobrażeń słuchowych) (Schuman 1952). Wyobraźnia muzyczna usytuowana jest wśród potencjalnych uzdolnień, rozwijanych przez kontakt z muzyką - stanowi obszar skłonności uwarunkowanych genetycznie lub pozyskanych na podłożu społeczno-kulturowym (np. doświadczenia muzyczne na wczesnym etapie życia) (Sacher 1997). Warunki specyficzne dla odbiorcy muzyki włączają w swój obszar tło kulturowe, trening muzyczny, konkretne doświadczenia, kontekst słuchania lub wykonania i stan afektywny słuchacza (Scherer, Zenter 2001), którego osobiste atrybuty mogą mieć znaczenie w konstruowaniu wyobrażeń słuchowych oraz ich późniejsze objaśnianie. 
Z uwagi na wyodrębnioną spośród innych rodzajów kategorię modalności słuchowej, szczególny rodzaj wyobrażeń stanowią wyobrażenia muzyczne (Hargreaves, Mieli, McDonald 2011; Zatorre, Halpern 2005). Pod względem posiadania lub braku informacji sensorycznej (muzycznej) mogą one występować w dwojakiego rodzaju kontekstach, kształtując dwa typy wyobrażeń: a) abstrakcyjne - tj. takie, które pojawiają się bez udziału poczucia słyszenia materiału muzycznego (np. melodii, barwy instrumentu); b) ejdetyczne - tj. takie, które zawierają różnorodny i obfity materiał sensoryczny. Wśród pojawiających się powyższych dwóch zasadniczych typów wyobrażeń można wyodrębnić dodatkowo tzw. wyobraźnię przewidującą, która opiera się na wyobrażeniach bazujących na odbiorze muzyki przy udziale zaangażowanej uwagi. Jest to wyobrażanie sobie dźwięków przez odbiorcę, zanim je on usłyszy przy posiadaniu danego zasobu wiedzy muzycznej i osobowego potencjału.

Wyobrażenia muzyczne mają odniesienia do procesu wyobrażania sobie dźwięków, czyli odwołują się do słuchu wewnętrznego - będącego zdolnością do myślowego wyobrażania bez udziału akcesoriów i czynności muzycznych: instrumentów, głosu, wokalizacji, tonów muzycznych oraz zachodzących między nimi relacji (Tiepłow 1952). W przypadku dźwięków istotne znaczenie dla wyobrażeń odtwórczych (tj. rozumianych jako uwewnętrznione tworzenie wiernego obrazu) ma struktura czasowa wyobrażonego bodźca (np. wzory czasowe) (Schaefer 2014). Bodziec ten jest traktowany jako sygnał słuchowy i wpływa na zwiększenie się obrazowości motorycznej oraz sekwencji ruchowej (Heremans, in. 2009; Keller, Appel 2010). Wyobrażenia słuchowe - są wytworem atrybutywnym zjawiska twórczości (Szmidt 2007) i zawierają strukturę czasową oraz zjawisko oczekiwania (np. dla obrazów skal tonalnych) (Janata, Paroo 2006) oraz są aspektem mózgowej podstawy (Schubotz i in. 2000) wystąpienia wyobraźni muzycznej. Wśród niektórych naukowców (kognitywiści) występuje tendencja, aby badać przejawy wyobraźni muzycznej na drodze pomiaru aktywacji ścieżek neuronowych podczas percepcji wyobrażonej lub rzeczywistej muzyki (Brown, Palmer 2012; 2013; Pecenka i in. 2013). Czynność pomiarowa na poziomie funkcji neuronalnych odnoszona jest do psychologicznych oraz społeczno-kulturowych aspektów wyobraźni muzycznej, aby móc wyjaśnić to zjawisko w kontekście motorycznych przejawów (np. czytanie nut, improwizowanie na instrumentach, trening muzyczny). Badacze przyznają, że obrazy (reprezentacje) mentalne stanowią swoistą pomoc w osiągnięciach i praktyce muzycznej (Parncutt 2007; Holmes 2005), a wyobraźnia muzyczna (słuchowa) oraz ruchowa, a także trening mentalny - mogą przekładać się na działania w obrębie ekspresji emocjonalnej (np. w tańcu) lub wspomagać uczenie się w obszarze motoryki (Brown, Palmer 2013), co odgrywa zasadniczą rolę w wykonawstwie muzycznym. Ponadto stwierdzono, że proces i czynność (ruchowa) przejścia do wyobrażonej muzyki aktywuje sieć motoryczną mózgu w sposób bardziej nasilony, niż kiedy występuje w kontekście upodobnionych ruchów, ale już bez obecności obrazów muzycznych (Schaefer, in. 2014). Prowadzone w ostatnim czasie badania wskazują, że w pojawianiu się 
odpowiedzi na percepcję muzyki (fragm. Symfonii $n r$ 9, L. van Beethovena) oraz stymulowanie słuchacza obrazem wzmacnia się aktywację wyobrażeń muzycznych, zwłaszcza w obszarze Wernickiego (Zhang i in. 2017).

Modułowość sensoryczna „umysłu muzycznego” jest punktem wyjścia do szeregu poszukiwań związanych z procesami wyobrażeniowymi, występującymi na podłożu słuchowym: wysokościowym, melodycznym, harmonicznym, rytmicznym, barwowym, dynamicznym (Manturzewska 1990). Pozwala to na częściowe rozpoznawanie operacji psychicznych, leżących u podstaw wyobraźni muzycznej - pozwalającej wyobrażenie przełożyć na: śpiew, grę na instrumencie, kompozycję, aranżację, dyrygowanie zespołem. Przekaz muzyczny zawiera informację spoza semantyki (np. strukturalną i czasową), co wytwarza zapotrzebowanie na aktywność obydwu półkul. Muzyka, regulując funkcje poznawcze, wpływa na zachowanie równowagi między czynnościami półkul a niektórymi zdolnościami (np. językowymi, wzrokowo-przestrzennymi), co ma przełożenie na związki między treningiem muzycznym a inteligencją (Hargreaves, Aksentijevic 2011, s. 307; Hannon, Trainor 2007). Pojawiają się konceptualizacje wskazujące na to, iż wyobraźnia słuchowa jest twórczym działaniem, gdyż łączy wpływ zbiorowości ludzkich i środowiska kulturowego, w obrębie których zachodzi. Interakcje przebiegające między czynnikami wiążącymi słuchacza (ekspert, amator, nie-ekspert) z sytuacyjnym kontekstem słuchania czy samą muzyką (tzw. sieci) - mogą wyznaczać reakcję osoby na percypowaną muzykę, stając się odniesieniem do powstających wyobrażeń (Hargreaves, Hargreaves, North 2012). Tworząc wyobrażenia i muzyczne odniesienia słuchowe, ludzie mogą posługiwać się $\mathrm{w}$ ich generowaniu uprzednim, indywidualnym zestawem doświadczeń muzycznych, gromadzonym i przechowywanym w systemie mentalnym oraz cielesnym. Jako przykład jest podawana relacja między kompozytorem, będącym w ciągłej relacji z uwewnętrznioną kafeterią utworów i wszelkich doświadczeń muzycznych, a jego kontaktem ze słuchaczem (Folkestad 2012, s. 189). Inna perspektywa wskazuje, że kreując wyobrażenia słuchowe, ludzie posługują się matrycą połączeń między utworami muzycznymi a bogatą gamą kulturowych skojarzeń - mogą nimi być często spotykane sytuacje lub typowe ich konteksty, doświadczane słuchowo. W kontekście pojawiania się słuchowej wyobraźni takie kulturowe skojarzenia mogą dotyczyć upodobań (preferencji) muzycznych bądź awersji do określonych gatunków i rodzajów muzyki (Martindale, Moore 1989; za: Hargreaves, Miell, MacDonald 2012).

Paradygmat wyobraźni muzycznej, ujmowanej jako zdolność poznawcza całego organizmu, usytuowanego $\mathrm{w}$ środowisku, przedstawiany bywa jako koncepcja wielopoziomowego mechanistycznego wyjaśniania pojęcia wyobraźni muzycznej (Matyja, Schiavio 2013). Termin wyobraźnia muzyczna jest zazwyczaj wtedy rozumiany jako zdolność poznawcza ludzkiego organizmu, którą konstytuują określone składniki traktowane jako funkcje: symulowanie (Schiavio i in. 2015); 2) integracja danych zmysłowych; 3) tworzenie twierdzeń, które odnoszą się do: a) ucieleśnionych interakcji muzycznych - spełniających daną rolę w percepcji 
oraz produkcji (tworzenia) muzyki; oraz b) samej muzyki. Mentalne integrowanie obrazu (wyobrażenia) z jego akustycznym odpowiednikiem (dźwiękiem) występuje w wykonaniu muzycznych dzieł artystycznych, gdy materiał podlega ćwiczeniom mentalnym: $z$ dala od instrumentu, partyturze rozczytywanej w myślach, wyobrażaniu wzorcowego dźwięku (Zatorre, Halpern 2005; Keller 2012). Przewidywanie zadań obrazowania w modalności słuchowej (Kosslyn, Thompson 2003), które mogą wskazać na występowanie aktywacji w rejonach pierwotnych mózgu, traktowane jako przejaw reprezentacji mentalnych (wyobrażeniowych), jest niewystarczające. Obecne rezultaty badawcze zawierają informacje o wielu procesach psychicznych, wymagając doprecyzowania i większej liczby badań na licznych próbach.

Problematykę wyobraźni muzycznej warto nieco poszerzyć o kontekst zaburzeń - pojawiających się w ludzkim doświadczeniu, np. w formie - halucynacji słuchowych. Halucynacje muzyczne (ang. music hallucination) - stanowią jedynie pewną składową halucynacji słuchowych oraz słuchowo-werbalnych, opisywanych jako doznania form muzyki wewnętrznej (np. melodii, harmonii) obecnych w wyobraźni muzycznej. Innymi przykładami halucynacji muzycznych są: robaki uszne, obrazy muzyczne, doświadczenia mieszane. Halucynacje muzyczne definiuje się jako świadome doświadczanie dźwięków (zazwyczaj przy utracie słuchu), których występowanie nie jest wzbudzane przez rzeczywiste bodźce sensoryczne obecne w otoczeniu (np. słyszenie muzyki/piosenki, kiedy nikt nie gra/nie śpiewa/ nie słyszy) (Moseley i in. 2018). Pod względem klinicznym identyfikowane są jako specyficzne zjawiska postrzegane w lokalizacji przestrzennej, ale pojawiające się poza kontrolą wolicjonalną u osób z rozpoznaniem zaburzeń neurologicznych (np. szumy uszne, utrata/upośledzenie słuchu) i psychicznych (np. schizofrenia, depresja, wpływ substancji psychoaktywnych). Inną formą halucynacji są halucynacje hipnagogiczne, czyli każde halucynacje pojawiające się w okresie przejściowym między czuwaniem a snem (np. artefakty wydawania dźwięku, takie jak - oddech wykonawcy, słyszalne postukiwania smyczkiem czy trzaski). Mają na nie wpływ bodźce świetlne w swej intensywności oraz mechanizmy biologiczne człowieka. Świadomość istnienia różnych form wewnętrznego doświadczenia muzycznego wymaga odrębnej, pogłębionej analizy, która nie jest przedmiotem tego opisu, lecz stanowi jedynie wzmiankę o tym zagadnieniu z punktu widzenia klinicznych i terapeutycznych zastosowań w medycynie, muzykoterapii i terapii muzyką.

\section{Terapeutyczny aspekt wyobrażeń (muzycznych)}

Proces powstawania wyobrażeń, postrzegany przez psychologię jako: zdolność do tworzenia wyobrażeń zmysłowych (Kosslyn i in. 2006), posiadanie dyspozycji skojarzeniowych pokrewnych myśleniu asocjacyjnemu bądź przejaw procesów symulacji mentalnej (Taylor i in. 1989), jest obecny w zagadnieniach dotyczących funkcji muzyki, jakie pełni ona w lecznictwie i terapii. Muzykoterapia stanowi dziedzinę wspomagającą proces leczenia ciała i psychiki, która opiera się na systematycznym 
i metodycznym zastosowaniu muzyki w diagnozie, leczeniu schorzeń, rozwoju osobowości, a także zapobiegawczo w profilaktyce w celu zaktywizowania lub uspokojenia osoby. Ogólnorozwojowy aspekt muzykoterapii jest obecny jako komponent praktyk w każdym jej nurcie, jednak szczególnie istotny jest w muzykoterapii pedagogicznej (pedagogika ogólna i specjalna), która stosuje tzw. muzykoterapię o charakterze spontanicznym, opartą na improwizacji i swobodnym muzykowaniu. Charakter pracy terapeutycznej bazującej na spontanicznej aktywności z udziałem muzyki jest ważną sferą muzykoterapii na poziomie głębokim, czyli muzykoterapii wglądowej (np. psychoanalitycznej, psychodynamicznej) o celach rekonstrukcji doświadczeń - stosowany wobec osób z zaburzeniami adaptacyjnymi, zaburzoną osobowością, fobiami (Crowe 2007). Pod pewnym względem zbliżony rodzaj pracy terapeutycznej z udziałem technik improwizacji (instrumentarium Orffa) stosowany jest w pedagogice (specjalnej) i edukacji szkolnej. Umożliwia on jednostce pozyskiwanie doświadczenia natury poznawczej, komunikacyjnej i emocjonalnej w sposób swobodny oraz transformowanie negatywnych doświadczeń na pozytywne, co naturalnie wymaga empirycznej weryfikacji. Przedstawiciele muzykoterapii psychoanalitycznej powiedzieliby, że zastosowanie improwizacji sprzyja przełożeniu treści nieświadomych na grunt prewerbalnej komunikacji, skierowany na sferę werbalną i świadomą. Dzięki symbolicznej płaszczyźnie muzycznej, związanej z wyobraźnią i metaforyką, korygowanie negatywnych doświadczeń sprzyja spontanicznej ekspresji i odkrywaniu pozytywnych doznań, ułatwiając jednostce kontakt ze sobą i innymi. Muzykoterapia w nurcie psychodynamicznym oraz taka, która posługuje się technikami improwizacji, pomaga w spontanicznym tworzeniu i uruchamianiu sfery symbolicznej, która jest odrębnym doświadczeniem każdej osoby. Muzyka, ułatwiając projekcję wyobrażeń i ekspresję emocji, aktywizuje procesy poznawcze: pamięć, wspomnienia, wyobraźnię. Dzięki swym specyficznym właściwościom muzyka przenika do niedostępnych warstw osobowości, wspomagając myślenie metaforyczne i wydobycie treści z podświadomości. Uzupełnienie niewerbalnych oddziaływań, u podłoża których znajduje się proces wyobrażeniowy, kreatywność i wyobraźnia (np. improwizacja, muzyczny dialog na instrumentach), o oddziaływania technikami werbalnymi (np. dialog, skojarzenia, wyobrażenia) oraz opartymi o ukierunkowaną/nieukierunkowaną spontaniczność, pozwala na osiąganie celów terapeutycznych przy użyciu muzyki. Metafizyczne koncepcje muzykoterapii odnoszone do złożoności samej muzyki (np. W. Frankl, H. Giltay, L. Grote), podkreślają aspekty duchowe, transcendentne i estetyczne $\mathrm{w}$ terapii. Proces terapeutyczny z zastosowaniem muzyki zawiera w sobie swoisty obszar estetyki i współistnieje z pojęciami takimi, jak: twórczość, intuicja, intencja. Muzykoterapia w swej złożoności odwołuje się do wewnętrznych stanów człowieka, podkreślając podejście personalistyczne. Uwzględnia w dyskursie nierozstrzygnięte dotychczas kwestie samej muzyki. Z jednej strony stawia pytania o to, czy muzyka coś znaczy i przekazuje, co może prowadzić do kontekstowego odczytywania muzyki (np. semiotyka, estetyka muzyczna, muzyka programowa, 
symbolika). Z drugiej strony odnosi się do kwestii muzyki rozumianej jako sztuka nieprzedstawiająca i asemantyczna, czyli niepozostająca w żadnym związku z rzeczywistością pozamuzyczną, lecz będącą sztuką autonomiczną - tj. o najwyższym stopniu abstrakcji. Koncepcje tego rodzaju oraz pytania o rolę i funkcję muzyki $\mathrm{w}$ procesie terapeutycznym współistnieją równolegle z pozytywistycznym paradygmatem naukowym, ukierunkowanym na badanie rzeczywistości metodami empirycznymi. Eklektyczne ujęcie muzykoterapii stara się łączyć te z natury odmienne wobec siebie podejścia, proponując szerokie i komplementarne względem siebie spektrum terapeutycznych oddziaływań. Muzykoterapia jako forma wspierania rozwoju i proces wewnętrznych zmian u osoby - pobudza wyobraźnię, wpływa na ekspresję twórczą, komunikację i inspiruje do swobodnego myślenia oraz spontanicznego działania. W muzykoterapii wyobraźnia znajduje swoje miejsce w twórczym rozwoju muzyki improwizowanej, który nawiązuje do aspektów improwizacji jako siły twórczej i napędza doświadczenie o potencjał abstrakcyjnych obrazów, tematów, a także sieci skojarzeń pobudzanych muzyką. Wpisana w te zjawiska problematyka specyfiki wyobraźni dźwiękowej (słuchowej), której swoistą właściwością jest „beztreściowość” i trudności w przełożeniu materiału dźwiękowego na całości znaczeniowe, stanowi wyzwanie dla wielu muzykoterapeutów. Zajmujący się specyfiką różnorodnych zaburzeń (słuchowych, neurologicznych czy choćby afektywnych) obserwują u osób leczonych trudności w percypowaniu dźwięków i tworzeniu sieci wyobrażeniowych.

W terapii chorób i zaburzeń używa się dźwięków i muzyki, prócz korzystania z interdyscyplinarnych założeń metodycznych, psychologicznych i muzykologicznych. Leczenie muzyką opiera się na zastosowaniu wielu technik, w tym relaksacyjnych, niewerbalnych i werbalnych, które oparte są o komunikację, a zostają użyte $\mathrm{w}$ procesie terapii $\mathrm{w}$ celu uzyskania i przywrócenia równowagi między psychiką i ciałem. Muzyka oddziałuje na ludzki mózg, przez co może zmieniać jego funkcje i struktury, znajdując zastosowanie w leczeniu chorób neurodegeneracyjnych oraz ma swoje miejsce w muzykoterapii neurologicznej. Badania obrazowania mózgu pokazują, że wyobrażanie sobie czegoś (np. zagrożenia) uruchamia podobne rejony, jak w przypadku doświadczania czegoś w sposób realny. Wyobraźnia jest rzeczywistością natury poznawczej i neurologicznej, która może wpływać na mózg i ciało w sposób istotny dla dobrego samopoczucia. Muzyka angażuje kanał słuchowy do analizy podstawowych cech dźwięków (np. wysokości, głośności) (I-rzędową korę słuchową i okolice zakrętu Helschla) oraz do przetwarzania złożonych zasad organizacji dźwięków w czasie i względem ich głośności (np. rytm, harmonia, kontur melodyczny) (II-rzędowe okolice słuchowe), uruchamia nieświadome operacje umysłowe: pamięć, uwagę, emocje, procesy wyobrażeniowe, motoryczne. Materia muzyczna oddziałuje na obszary układu limblicznego, korę przedczołową i okolice grzbietowe - wzbudza odpowiedź afektywno-estetyczną i zdejmuje blokadę w obrębie emocjonalnych doświadczeń. Przywołuje ślady pamięciowe i wyczucie 
czasu oraz funkcje werbalne (Demarin i in. 2016), a wraz z nimi wspomnienia (Galińska 1995).

Muzykoterapia jest narzędziem mnemonicznym, które wspomaga i usprawnia pamięć, a także pozwala wykorzystać muzykę do regulowania procesami biologicznymi (rytm biologiczny człowieka, układ oddechowy, sercowo-naczyniowy, hormonalny) i psychicznymi (np. procesy mentalne, emocje, nastrój). Na tym tle zakorzenienie nurtów muzykoterapii w treściach humanistycznych i w odmiennych perspektywach mentalnych (np. fenomenologicznej, filozoficznej, psychoterapeutycznej, w filozofii muzyki, estetyki) rozszerza specyficzny potencjał sztuki muzycznej i jej potencjalny wpływ (pozytywny $v s$ negatywny) na odbiorcę pozostającego w terapii. Zaprzątanie myśli największych filozofów, począwszy od Platona i Arystotelesa, kwestiami uświadomienia sobie istnienia wyobraźni, obecne jest na swój sposób w oddziaływaniach terapeutycznych z udziałem materii dźwiękowej. Arystoteles określił wyobraźnię mianem mimesis (pierwotnie rozumiana jako ekspresyjność $\mathrm{w}$ tańcu), czyli jako zasada twórczego naśladownictwa natury lub dzieł mistrzów, którzy próbowali tę naturę odtworzyć. Przy czym zaakcentować można, iż naśladowanie (przyrody) u Arystotelesa nie oznacza odbicia, odwzorowania czy kopii, co niekiedy wywołuje polemikę z ujęciem muzyki reprezentowanym przez Platona. Umiejscawiając muzykę między myślą a zmysłami, Arystoteles otworzył ludzkość na inną, nierozpoznawalną dotychczas jakość.

Abstrahując od tych zawiłych zagadnień, w sensie terapeutycznych rozwiązań warto nadmienić, iż muzykoterapia w psychoterapii używa różnorodnych technik o charakterze projekcyjnym, opartych na mechanizmie percepcji muzyki i nakierowuje pacjenta na dany problem. Muzykoterapia zakłada, że człowiek jest istotą kreatywną i wystarczy niekiedy zastosowanie odpowiednich narzędzia oraz technik, aby odkryć w nim ukryte możliwości. Muzyka pobudza wyobraźnię i fantazję, umożliwia dotarcie do głęboko ukrytych problemów i uzewnętrznienie emocji, zablokowanego napięcia. W praktyce muzykoterapii proces wyobrażeniowy można wzbudzać przez zastosowanie tzw. instrukcji wyobrażeniowej (jawnej lub niejawnej). Jest ona znana w tzw. teorii wyobraźni S. Kosslyna, lecz zwykle łączona jest z pamięcią asocjacyjną (Kosslyn 2005). Instrukcja jawna, wzbudzając wyobrażenie, zawiera złożone sekwencje słowne i ma werbalne sformułowanie (np. „wyobraź sobie...”). Instrukcja ukryta, dla której nośnikiem wyobrażenia jest muzyka - nie przekazuje prawdziwej treści i nie ma sformułowań językowych, lecz korzysta z metafor, zaskakujących porównań (Francuz 2007). Procesy wyobrażeniowe z udziałem odbioru muzyki, które korzystają z nieświadomych mechanizmów obecnych w projekcji i identyfikacji, są integralną częścią doświadczenia wewnętrznego, kiedy obserwuje się zewnętrzne wpływy środowiska społeczno-kulturowego. Złożony materiał muzyczny stosowany w działaniach terapeutycznych względem pacjentów ma dodatni wpływ na pobudzenie wyobraźni oraz ujawnianie się kreatywności, inspirując zachowania twórcze (Sovansky i in. 2016; Kokotsaki, Newton 2015; Cominardi 2014). Doświadczając kreatywności podczas 
terapii muzycznej (np. w technice songwritting - tj. pisania piosenek), i realizując jej dążenia, stwarza się dogodne warunki do wyrażania wielu stanów emocjonalnych i innych doświadczeń, co może mieć przełożenie na powoływanie nowych sposobów wyrażania siebie i radzenie sobie poza zbiorowością terapeutyczną (Heath, Lings 2012; Ahmadi 2011). Interwencje terapeutyczne, korzystające $\mathrm{z}$ wartości działań cechujących się kreatywnym aspektem wyobrażeń, występują w parze $\mathrm{z}$ improwizacją (gra na instrumentach) (Nordoff-Robbins 2007), twórczym komponowaniem i swobodną eksploracją (Hargreaves 2012). Wyobraźnia muzyczna, czyli zdolność operowania wyobrażeniami dźwięków i słyszenia muzyki w sobie, rozumienia, interpretowania i tworzenia - jest w oddziaływaniach terapeutycznych podporządkowana celom terapii.

Procesy wyobrażeniowe, stymulowane akustycznym nośnikiem treści muzycznych, mają odniesienia do funkcji muzyki, a te uzasadniają tworzenie i klasyfikację technik muzykoterapeutycznych. W strukturze ich podziału można dostrzec akcenty przypadające na rolę procesów związanych z wyobraźnią muzyczną - niezawierającą bodźca muzycznego lub występującą w kontakcie z nim. Zestaw technik, stworzony przez E. Galińską w ramach polskiej szkoły muzykoterapii klinicznej, jest różnorodny (Galińska 1977). Klasyfikację technik muzykoterapii (klinicznej), dokonaną przez E. Galińską przedstawia poniższa tabela nr 1 (Galińska 1997).

Tabela 1. Klasyfikacja technik stosowanych w muzykoterapii - E. Galińska (1997)

\begin{tabular}{|l|l|}
\hline \multicolumn{1}{|c|}{ Nazwa grupy technik } & \multicolumn{1}{|c|}{ Zastosowanie } \\
\hline $\begin{array}{l}\text { Odreagowująco- } \\
\text {-wyobrażeniowe }\end{array}$ & $\begin{array}{l}\text { Stosowane w metodzie „portretu muzycznego”: a) lustra dźwię- } \\
\text { kowego pacjenta; b) lustra muzycznego („kolażu muzycznego”). }\end{array}$ \\
\hline Aktywizujące emocjonalnie & Stosowane w metodzie „portret Muzycznego”, psychodramie. \\
\hline Treningowe & $\begin{array}{l}\text { Stosowane w terapii behawioralnej, muzycznym treningu } \\
\text { uwrażliwienia. }\end{array}$ \\
\hline Relaksujące & $\begin{array}{l}\text { Stosowane w różnych dziedzinach medycyny i nurtach } \\
\text { muzykoterapii. }\end{array}$ \\
\hline Komunikatywne & $\begin{array}{l}\text { Związane z komunikacją społeczną (techniki sytuacyjne, } \\
\text { ekspresyjne). }\end{array}$ \\
\hline Kreatywne & $\begin{array}{l}\text { Stosowane w formie improwizacji (społecznej, wokalnej } \\
\text { i ruchowej). }\end{array}$ \\
\hline Psychodeliczne & Ekstatyczne, katarktyczne, estetyzujące, kontemplacyjne. \\
\hline Wibracyjno-akustyczne & Stosowane w stymulacji wibroakustycznej w terapii. \\
\hline
\end{tabular}

Źródło: opracowanie własne.

Proces wyobrażeniowy, nazywany tu wyobraźnią, jest stymulowany przez zastosowanie technik muzykoterapii opartej na percepcji (tzw. techniki kierowanej wyobraźni, „lustra muzycznego”, składnika metody "portretu muzycznego” E. Galińskiej) bądź na aktywnych formach wykonawczych, w których na uwagę zasługują techniki: a) odreagowująco-wyobrażeniowe, b) kreatywne i c) relaksacyjne. 
W technikach odreagowująco-wyobrażeniowych proces terapeutyczny ma wzbudzać powstawanie zmian i wpływać na pobudzenie intensywności projektowanych wyobrażeń (wzrokowych, słuchowych), generujących skojarzenia muzyczne i/lub pozamuzyczne. Rezultat tych działań prowadzi do wywołania reakcji behawioralno-emocjonalnych (dreszcz, płacz, ciepło, zimno) i wyzwala zablokowaną energię afektywną. Zasadniczym celem stosowania technik odreagowująco-wyobrażeniowych jest podmiotowo-jakościowe badanie struktury osobowości jednostki, czemu służą zadania ukierunkowane na swobodne wyobrażenia dotyczące postaci, z którą identyfikuje się osoba. Zastosowany w nich mechanizm identyfikacji z muzyką sprzyja projekcji wolnych skojarzeń: wzrokowych, słuchowych, werbalnych (Galińska 1991). Przykłady technik kierowanej wyobraźni są znane w literaturze (Bonny 1994; Summer 2002; Bruscia 2002; Burns 2001), a ich nazwy zawierają się w swoistych etykietach - będących niekiedy początkiem tematów, jakie otrzymują pacjenci (Galińska 1995): a) wyobrażenie postaci; b) zaczarowany ogród; c) podwodne miasto; d) ja - jako biały i czarny; e) ja - w roli zdobywcy; f) ja - jako władca i poddany; g) w grocie Wenus; moja walka z królem; h) wyobrażenie sobie złej postaci (potwora); i) wyprawa w góry, przez morze, pustynię, itp.; j) metaforyczne określenie relacji z osobami bliskimi z rodziny etc. Unikalne (ekspresyjne, estetyczne, kreatywne, harmonizujące) właściwości muzyki pozwalają osobie funkcjonować jako obiekt przejściowy, bądź „kontener” - w sensie psychologicznym, stanowiąc odniesienie dla emocjonalnego doświadczenia (Abram 2001).

Techniki kreatywne są formami aktywnymi rozwijającymi dyspozycje twórcze podmiotu, w których swoboda wyobrażeń muzycznych manifestuje się przez improwizację instrumentalną, wokalną i ruchową. Wśród znanych w tym nurcie technik znajdują się „rondo rytmiczne” oraz „kanon rytmiczny” - proste formy muzyczne, realizowane przez osoby na instrumentach muzycznych. Możliwe jest też korzystanie z kanonów głosowych i głosowo-ruchowych przy akcencie padającym na puls i swobodną motorykę. Istotnym czynnikiem tych technik jest integrująca rola tworzenia i wykonania muzycznych produkcji twórczych lub odtwórczych, dokonująca się w obrębie zbiorowości (np. terapeutycznej).

Techniki relaksacyjne - używane w różnych dziedzinach medycyny i stosowane $\mathrm{w}$ wielu nurtach muzykoterapii mają na celu uzyskanie stanu odprężenia psychicznego, wejścia w atmosferę relaksu i wyciszenia. $\mathrm{W}$ ramach tych technik korzysta się z odpowiednio przygotowanych zbiorów nagrań muzycznych oraz zachęca się osoby do samodzielnego współtworzenia muzyki. Zastosowane odmiennego rodzaju zadań stawia osoby w pozycji biernego odbiorcy treści muzycznych lub aktywnego współtwórcy. Procesy wyobrażeniowe, obecne w działaniach związanych z wizualizacją muzyki, mają wzbudzać u osób będących w terapii stany afektywne - jako emocjonalna i behawioralna odpowiedź na oddziaływanie muzyki. Korzyści związane $\mathrm{z}$ działaniami muzykoterapeutycznymi są postrzegane jako pozamuzyczne, lecz płynące bezpośrednio z działań muzycznych, gdzie symbolizacja, obrazowanie, fantazja i zdolność do kreatywnego poszerzania rzeczywistości w procesie 
wyobrażania sobie własnego świata lub elektronicznego symulowania zjawisk zyskuje właściwe miejsce wśród różnorodnych terapeutycznych oddziaływań.

W kontekście wyobraźni i procesów wyobrażeniowych w terapii powinno się uwzględniać w muzykoterapii zagadnienia neuropsychologiczne, związane $\mathrm{z}$ agnozją (ang. a-gnosis, czyli brak wiedzy). Jest ona rozumiana jako niezdolność do odczytania istotnych aspektów informacji z sygnałów płynących od zmysłów. Wśród agnozji można rozróżnić agnozje słuchowe, które dzielą się na trzy rodzaje: a) amuzję (tj. z niezdolnością do rozpoznawania wysokości dźwięku/barwy instrumentu/poczucia rytmu z powodu niewłaściwego przetwarzania informacji słuchowej przez mózg); b) agnozję semantyczno-skojarzeniową - tj. zaburzenia słuchu fonematycznego, powodujące trudności w rozróżnianiu wyrazów, a co za tym idzie, upośledzenie własnej mowy - nie słyszy się różnic; c) amuzję wyobrażeniową - tj. niezdolność (częściowa lub całkowita) do wyobrażenia sobie konkretnych dźwięków, brzmienia i wysokości dźwięku, melodii. Amuzja wyobrażeniowa jest tematem, który czeka na odkrycie we współczesnej neuropsychologii. Agnozje słuchowe mogą stanowić ciekawy kierunek badań rzucający nową perspektywę na psychologię różnic indywidualnych i psychologię muzyki, w tym na teorię i praktykę muzykoterapii, która potencjalnie nawiązuje łączność własnych, leczniczych oddziaływań na jednostkę/grupę z zagadnieniami dotyczącymi wyobraźni, wyobrażeń, fantazji oraz halucynacji i iluzji.

\section{Konkluzja}

Refleksja nad problematyką wyobraźni, pojawiającą się w wielu kontekstach: zdolności poznawczych, procesów o podłożu twórczym i odtwórczym, słuchowym (muzycznym), kreatywności, wyobrażeń muzycznych - nie wyczerpuje zakresu podejmowanej tematyki, lecz tylko stanowi jej zarys. Niektóre z poruszanych wątków tematycznych koncentrują się na złożoności procesów mentalnych i wyobrażeniowych, które występują w interakcji właściwości ludzkiej psychiki ze specyficznymi właściwościami muzyki, mającymi przełożenie na procesy terapeutyczne. Mentalne tworzenie i odtwarzanie muzyki w sytuacji nieobecności bodźca muzycznego, stanowiące wyraz wyobraźni (muzycznej) oraz mentalne obrazy muzyki pod obecność bodźca muzycznego - są rezultatem współdziałania procesów psychicznych, pojawiających się w procesie terapeutycznym. Stymulująca wartość jakościowa i akustyczna muzyki, uwzględniona w wielopłaszczyznowej problematyce dotyczącej wyobrażeń (muzycznych), stanowi punkt wyjścia do podejmowania działań o charakterze eksploracyjnym w podejściu ilościowym, które uzupełni refleksję nad prezentowanym zagadnieniem. Poszerzenie rozumienia wyobraźni muzycznej o paradygmat wielopoziomowego wyjaśnienia mechanistycznego (Matyja 2015) w kontekście badań nad wyobraźnią muzyczną jako zdolnością poznawczą całego organizmu, przebywającego w środowisku, z pewnością otworzy refleksję nad tym zagadnieniem o kolejną perspektywę naukowych poszukiwań 
i teoretyczno-empirycznych wyjaśnień. Interdyscyplinarność działań, którą odnosi się do problematyki wyobraźni, a jest ona wielopoziomowym i wielozmysłowym doświadczeniem - służy głębszemu uświadomieniu możliwości artystycznej i terapeutycznej kreacji w zakresie sztuki (muzycznej). Wywodząc się z refleksji filozoficznej i estetycznej, problematyka wyobraźni wkracza na pole nowych możliwości, które otwierają przed nią modele naukowego poznania analogii między fikcją a rzeczywistością (w ramach projektu SCIMOD). Używając konkretnego rodzaju wyobraźni (tj. wyobraźni propozycjonalnej z umiejętnością „udawania prawdy”/wyobrażania rzeczywistości), wprowadzane współcześnie nowe metody naukowego budowania i weryfikowania hipotez stanowią odmianę twórczości, wykorzystującej atrybuty wyobraźni i procesów wyobrażeniowych. Refleksja nad znaczeniem wyobraźni w psychologii, w sztuce (muzycznej) i jej wykorzystania w terapii zaburzeń stanowi wielowątkową i wielodyscyplinarną interpretację fenomenu, jakim jest wyobraźnia. Jej muzyczny aspekt stanowi swoistą oznakę wewnętrznej różnorodności, żywej obecności i niewyczerpanej siły kryjącej się w wyobraźni.

\section{Bibliografia}

Abram B. (2001). Music, cancer, and immunity. „Clinical Journal of Oncology Nursing", nr 5, s. 22-224.

Ahmadi F. (2011). Song lyrics and the alternation of self-image. „Nordic Journal of Music Therapy", nr 20 (3), s. 225-241.

Anderson J.R. (1978). Arguments Concerning Representations for mental Imagery. „Psychological Rewiew”, nr 85 (4), s. 249-277.

Asma S.T. (2017). The Evolution of Imagination. The University of Chicago Press.

Barraca J., Poveda B., Artola T., Mosteiro P., Sanchez N., Ancillo I. (2010): Three version of a new test for assessing creativity in Spanish population (PIC-N, PIC-J, PIC-A). ECHA Conference, July 7-9, Paris.

Barrett H.C. (2005). Enzymatic computation and cognitive modularity. „Mind and Language", nr 20, s. 259-287.

Batey M., Furnham A. (2006). Creativity, intelligence and personality: A critical review of the scattered literature. "Genetic, Social, and General Psychology Monographs", nr 132, s. 355-429.

Bonny H.L. (1994). Twenty-one years later: A GIM update. „Music Therapy Perspectives", nr 12, s. 70-74.

Brown R.M. , Palmer, C. (2013). Auditory and motor imagery modulate learning in music performance. „Frontiers in Human Neuroscience” 2013, nr 7 (320).

Bruscia K. (2002). The boundaries of guided imagery and music (GIM) and the Bonny Method. W: Guided imagery and Music: The Bonny Method and beyond. Bruscia K., Grocke D. (red.). Gilsum New Hamphire: Barcelona Publishers, s. 37-61. 
Buchsbaum D., Bridgers S., Weisberg D.S., Gopnik A. (2012). The power of possibility: Casual learning, counterfactual reasoning, and pretend play. „Philosophical Transactions of the Royal Society, Biological Sciences”, nr 367, s. 2202-2212.

Burns D.S. (2001). The effect of the Bonny method of guided imagery and music on the mood and life quality of patients with cancer. "Journal of Music Therapy”, s. $38,51-65$

Chang Y.S. (2012). Students technological creativity using online problem-solving activities. „International Journal of Technology and Design Education”, s. 1-14.

Cominardi C. (2014). From creative process to trans-cultural process: Integrating music therapy with arts media in Italian kindergartens: A pilot study. „Australian Journal of Music Therapy", nr 25 (Special Issue: Regarding culture in music therapy), s. 3-14.

Cummins R.C. (2000). „How does it work?” vs. “What are the laws?”: Two conceptions of psychological explanation. W: Explanation and cognition. Keil F., Wilson R.A. (red.). Cambridge, Massachusetts: MIT Press.

Davis M.A. (2009). Understanding the relationship between mood and creativity: A meta-analysis. „Organizational Behavior and Human Decision Processes”, nr 100 (1), s. 25-38.

Demarin V., Bedeković M.R., Puretić M.B., Pašić M.B. (2016). Arts, Brain, and Cognition. „Psychiatria Danubina”, nr 28 (4), s. 343-348.

Dobrołowicz W. (2003). Antykreatywność - bariery psychiczne i psychospołeczne. W: Twórczość - wyzwanie XXI wieku. Dombrowska E., Niedźwiecka A. (oprac.). Kraków: Oficyna Wydawnicza IMPULS.

Domagała A., Mirecka U. (2012). Stuch mowny. Klasyfikacja zjawisk. W: Logopedia. Teoria zaburzeń mowy. Grabias S., Kurkowski M. (red.). Lublin: Wydawnictwo UMCS.

Folkestad G. (2012). Digital tools and discourse in music: The ecology of composition. W: Musical imaginations: Hargreaves D.J., Miell D.E., MacDonald R.A.R (red.). Oxford, UK: Oxford University Press, s. 189.

Francuz P. (2007). Teoria wyobraźni Stephana Kosslyna. Próba reinterpretacji. W: Obrazy w umyśle. Studia nad percepcja i wyobraźnią. Francuz P. (red.). Warszawa: Wydawnictwo Naukowe SCHOLAR, s. 179-183.

Galińska E. (1997). Psychoterapeutyczne założenia muzykoterapii i ich realizacja. „Psychoterapia”, s. 12, 22.

Galińska E. (1995). Analiza mechanizmów poznawczych muzykoterapii nerwic. „Psychoterapia”, nr 2 (93), s. 27-6o.

Galińska E. (1991). Muzykoterapia w kompleksowym leczeniu schizofrenii w warunkach oddziału dziennego. „Kwartalnik Psychoterapia” nr 3 (78), s. 43.

Guilford J.P. (1987). Natura inteligencji człowieka. Warszawa: PWN.

Encyclopedia of creativiti. (1999). Runco M.A., Pritzker S.R. (red.). Łódź: Wydawnictwo Academic Press. 
Hannon E.E., Trainor L.J. (2007). Music acquisition: Effects of enculturation and formal training on development. „Trends in Cognitive Sciences”, $\mathrm{nr}$ 11, s. 466-472.

Hargreaves D.J., Lamont A. (2017). The Psychology of Musical Development. Cambridge: Cambridge University Press, s. 49.

Hargreaves D.J. (2012). Musical imagination: Perception and production, beauty and creativity. „Psychology of Music”, nr 40 (5), s. 539-557.

Hargreaves. D.J., Hargreaves J.J., North A.C. (2012). Imagination and creativity in music listening. W: Musical imaginations. Hargreaves D.J., Miell D.E., MacDonaldR.A.R. (red.). Oxford UK: Oxford University Press, s. 156-172.

Hargreaves D.J., Aksentijevic A. (2011). Commentary: Music, IQ, and the executive function. „British Journal of Psychology”, s. 102, 306-308.

Hargreaves D.J. (2012). Musical imagination: Perception and production, beauty and creativity. „Psychology of Music”, nr 40 (5), s. 539-557.

Hargreaves D.J., Lamont A. (2017). The Psychology of Musical Development. Cambridge: University Press, s . 49.

Heath B., Lings, J. (2012). Creative songwriting in therapy at the end of life and in bereavement. „Mortality”, nr 17 (2), s. 106-118.

Heremans E., Helsen W.F., De Poel H.J., Alaerts K., Meyns P., Feys P. (2009). Facilitation of motor imagery through movement-related cueing. „Brain Res." 1278, s. 50-58.

Hokanson, B. (2006). Creativity in the design curriculum. „Journal of Visual Literacy", $\mathrm{nr} 26$ (1), s. 41-52.

Hornowski, B. (1978). Rozwój inteligencji i uzdolnień specjalnych. Warszawa: WSiP, s. 102.

Hurlock, E. (1985). Rozwój dziecka. Warszawa: PWN, s. 304.

Hsu Y., Peng L.P., Wang J.H., Liang C. (2014). Revising the imaginative capability and creative capability scales: Testing the relationship between imagination and creativity among agriculture students. „International Journal of Learning, Teaching and Educational Research", s. 6.

Janata P., Paroo K. (2006). Acuity of auditory images in pitch and time. „Perception \& Psychophysics", nr 68, s. 829-844.

Johnson-Laird P.N. (1980). Mental models in cognitive science PN JohnsonLaird. „Cognitive Science”, s. 4, 71-115.

Kaufman J.C. (2011). Kreatywność. Godyń M. (tłum.). Warszawa: Wydawnictwo Akademii Pedagogiki Specjalnej.

Karwowski M. (2010). Kreatywność - feeria rozumień, uwikłań, powodów. Teoretyczno-empiryczna prolegomena. W: Karwowski M., Gajda A. (red.). Kreatywność (nie tylko) w klasie szkolnej. Warszawa: Wydawnictwo APS.

Karwowski M. (2010). Sprzymierzeniec kreatywności. Warszawa: Wydawnictwo APS, s. 55-56.

Karwowski M. (2009). Identyfikacja potencjału twórczego. Warszawa: Wydawnictwo APS. 
Keller P.E. (2012). Mental imagery in music performance: Underlying mechanism and potential benefits. „Annals of the New York Academy of Science”, nr 122, s. 206-213.

Keller P.E., Appel M. (2010). Individual differences, auditory imagery, and the coordination of body movements and sounds in musical ensembles. „Music Perception", nr 28, s. 27-46.

Kokotsaki D., Newton D.P. (2015). Recognizing creativity in the music classroom. „International Journal of Music Education”, nr 33 (4), s. 491-508.

Kosslyn S.M. (2005). Mental images and the brain. "Cognitive Neuropsychology”, nr 22, s. 333-347.

Kosslyn S.M., Thompson W.L. (2003). When is early visual cortex activated during visual mental imagery, „Psychological Bulletin”, nr 129 (2003), s. 723-746.

Kosslyn S.M. (1994). Image and brain: the resolution of the imagery debate. Cambridge, MA: MIT Press.

Lacey S., Lawson R. (2013). Multisensory Imagery. Springer, New York-London.

Matyja J.R. (2015). The next step: mirror neurons, music, and mechanistic explanation. „Frontiers in Psychology”, 6 (April), nr 1-3.

Manturzewska M., Kotarska H., Miklaszewski L., Miklaszewski K. (1990). Zdolności, uzdolnienie i talent muzyczny. W: Wybrane zagadnienia z psychologii muzyki. Manturzewska M., Kotarska H. (red.). Warszawa: WSiP, s. 55.

Maruszewski (2002). Psychologia poznania. Sposoby rozumienia siebie i świata. Gdańsk: GWP, rozdz. 7, s. 2-428.

McDonald R.A., Miell D. (200o). Creativity and Music Education: The Impact of Social Variables. „International Journal of Music Education”, nr 36 (1), s. 58-68.

Mithen S. (1996). The Prehistory of the Mind. London: Thames and Hudson.

Moseley P., Alderson-Day B., Kumar S., Fernyhough h. (2018). Musical hallucinations, music imagery, and earworms: A new phenomenological survey. „Conscious Cong.", nr 65, s. 83-94.

Moulton S.T., Kosslyn S.M. (2009). Imagining predictions: mental imagery as mental emulation. „Philosophical Transactions of the Royal Society”, nr B (364), s. $1273-128$ o.

Mrymel M.K. (2003). Effects of using creative problem solving in eighth grade technology education class at Hopkins North Junior High School. Paper Project of Master in Science. University of Wisconsin-Stout.

Nęcka E. (2001). Psychologia twórczości. Gdańsk: GWP.

Nęcka E. (1995). Proces twórczy i jego ograniczenia. Kraków: Oficyna Wydawnicza „Impuls”, s. 18-30, 17.

Nordoff P., Robbins C. (2007). Creative Music Therapy: A Guide to Fostering Clinical Musicianship. Gilsum NH: Barcelona Publishers, s. 367-457.

Paivio A. (1986). Mental representations: a dual coding approach. Oxford UK: Oxford University Press. 
Paivio A., Lambert W. (1981). Dual coding and bilingual memory. „Journal of Verbal Learning \& Verbal Behavior", nr 20, s. 532-539.

Pecenka N., Engel A., Keller P. (2013). Neural correlates of auditory temporal predictions during sensorimotor synchronization. „Frontiers in Human Neuroscience”, nr 7 (August), s. 1-16.

Pelaprat E., Cole M. (2011). „Minding the gap”: imagination, creativity and human cognition. „Integrative Psychological and Behavioral Science”, nr 45, s. 397-418.

Pietrasiński Z. (1969). Myślenie twórcze. Warszawa: PZSW, s. 26, 1-149.

Przetacznikowa M., Makiello-Jarża G. (1982). Podstawy psychologii ogólnej. Warszawa: WSiP, s. 102.

Pylyshyn Z.W. (2002). Mental Imagery: In search of a theory. „Behavioral and Brain Sciences", nr 25 (2), s. 157-237.

Rank O. (1989). Art and artist. New York: Norton.

Ren F., Li X., Zhang H., Wang L. (2012). Progression of Chinese Students' Creative Imagination from Elementary Through High School. „International Journal of Science Education", nr 34 (13), s. 2043-2059.

Ribot T. (1901). O wyobraźni twórczej. Studium Psychologiczne. Warszawa: „Redakcja ma Głos", s. 112.

Runco M.A. (2003). Education for creative potential. „Scandinavian Journal of Educational Research", $\mathrm{nr} 47$.

Sacher W. (1997). O wczesnoszkolnej edukacji muzycznej. Kraków: Wydawnictwo „Impuls”, s. 25-26.

Schaefer R.S. (2014). Images of time: temporal aspects of auditory and movement imagination. „Frontiers in Psychology”, nr 5 (87).

Schaefer R.S. Morcom A.M., Roberts N., Overy K. (2014). Moving to music: effects of heard and imagined musical cues on movement-related brain activity. „Frontiers in Human Neuroscience", nr 8 (744).

Scherer K.R., Zentner M.R. (2001). Emotional effects of music productions rules. W: Music and emotion: Theory and research. Sloboda J.A., Juslin P.N. (red.). New York: Oxford University Press, s. 361-392.

Schubert E. (2012). Spreading activation and dissociation: A cognitive mechanism for creativity in music. W: Musical imaginations. Hargreaves D.J., Miell D.E., MacDonald R.A.R. (red.). Oxford: Oxford University Press, s. 124-140.

Schubotz R.I., Friederici A.D., Von Cramon D.Y. (2000). Time perception and motor timing: a common cortical and subcortical basis revealed by fMRI. „NeuroImage” nr 11, s. 1-12.

Schlutz A.M. (2009). Mind's world: Imagination and subjectivity from Descartes to Romanticism. Seattle. Washington: University of Washington Press.

Sokół A. (2015). Zarządzanie twórczością w organizacji. Warszawa: Wydawnictwo CeDeWu, s. 54-56.

Stevens W. (1965). The Necessary Angel: Essays on Reality and the Imagination. New York: Alfred a Knopf. 
Summer L. (2002). Group music and imagery therapy: Emergent receptive techniques in music therapy practice. W: Guided imagery and music: The Bonny method and beyond. Bruscia K.E., Grocke D.E. (red.). Gilsum, NH: Barcelona, s. 297-306.

Szmidt K. (2013). Trening kreatywności. Podręcznik dla pedagogów, psychologów i trenerów grupowych. Gliwice: Wydawnictwo Helion, s. 119,198-200.

Szmidt K.J. (2009). Współczesne podejścia w pedagogicznych badaniach nad twórczością: przegląd wybranych stanowisk. W: Metody pedagogicznych badań nad twórczością. Teoria i empiria. Szmidt K.J. (red.). Łódź: Wydawnictwo Akademii Humanistyczno-Ekonomicznej.

Schmidt K.J. (2008). Trening kreatywności. Podręcznik dla pedagogów, psychologów i trenerów grupowych, (e-book), s. 41-2 (druk, s. 19). Gliwice: Wydawnictwo Helion.

Szmidt K.J. (2007). Pedagogika twórczości. Gdańsk: GWP.

Sovansky E.E., Wieth M.B., Francis A.P., McIlhagga S.D. (2016). Not all musicians are creative: Creativity requires more than simply playing music. „Psychology of Music", nr 44 (1), s. 25-36.

Szuman S. (1956). Istota, kierunki i struktura uzdolnień muzycznych. „Szkoła Artystyczna", nr 1-2.

Szuman S. (1952). O sztuce i wychowaniu estetycznym. Warszawa: PZWS, s. 557-559.

Szymczak M. (2002). (red.). Słownik Języka Polskiego PWN, R-Z. Warszawa: Wydawnictwo Naukowe PWN, s. 518.

Szymczak M. (1981). Słownik języka polskiego. T. III. Warszawa: PWN, s. 572, 826.

Taylor R. Torres D., Boulanger P. (2005). Using music to interact with a virtual character. W: Proceedings of the International Conference on New Interfaces for Musical Expression, s. 220-223.

Thompson W.L., Hsiao Y., Kosslyn S.M. (2011). Dissociation between visual attention and visual mental imagery. „Journal of Cognitive Psychology”, $\mathrm{nr} 23$ (2011), s. $256-263$.

Tiepłow B. (1952). Psychologia zdolności muzycznych. Warszawa: Nasza Księgarnia, s. 15.

Torrance E.P. (1966). Torrance tests of creative thinking: Norms-technical manual. Princeton NJ: Personnel Press.

Treffinger D.J., Isaksen S.G., Firestein R.L. (1982). Handbook of Creative Learning. New York: Center for Creative Learning.

Vygotsky L.S. (2004). Imagination and creativity in childhood. „Journal of Russian and East European Psychology", nr 42 (1), s. 7-97 [oryg. publikacja wydana w 1930 roku. „Soviet Psychology”, nr 28 (1), s. 84-96].

Williams F. (1994). TCD. Test della creatività e del pensiero divergente. Trento: Erickson.

Witwicki W. (1962). Psychologia. T. 1. Warszawa: PWN, s. 336-340.

Witwicki W. (1975). Psychologia. T. 1. Warszawa: PWN, s. 342. 
Zawadzki R. (2005). Psychologia i twórczość. Warszawa: Wydawnictwa Szkolne i Pedagogiczne, s. 14.

Zatorre R.J., Halpern A.R. (2005). Mental Concerts: Musical Imagery and Auditory Cortex. „Neuron”, nr 47 (1), s. 9-12.

Zdankiewicz-Ścigała E., Maruszewski T. (2000). Wyobrażenia jako pierwsza forma doświadczenia generowanego przez jednostkę. W: Psychologia. Podręcznik akademicki. J. Strelau (red.). T. 2, Gdańsk: Gdańskie Wydawnictwo Psychologiczne, s. $183-203$.

Zhang Y., Chen, G., Wen H., Lu K-H., Liu Z. (2017). Musical Imagery Involves Wernicke's Area in Bilateral and Anti-Correlated Network Interactions in Musicians. „Scientific Reports” 7, nr 17066.

\section{THE OBJECT OF COGNITION - IMAGINATION (MUSIC)}

Abstract: The aim of the article is to present a reflection on the multidimensional issue of imagination. The definition and concept of imagination and imaginings in selected contexts are presented: creative vs. reproductive imagination, creativity potential and music therapy. Musical imagination, occurring in the auditory modality, was explained, signaling the therapeutic aspect of musical imagination.

Keywords: (musical) imagination, imagery, creativity, music therapy. 